\title{
Factorial analysis of trace elements of Tamarindus indica with reference to Bela ophiolite
}

\author{
Salma Hamza ${ }^{1 *}$, Shahid Naseem ${ }^{1}$, Syed Nawaz-ul-Huda ${ }^{2}$, Erum Bashir ${ }^{1}$, Farkhunda Burke ${ }^{2}$, \\ Shamim Ahmed Sheikh ${ }^{1}$ \\ ${ }^{1}$ Department of Geology, University of Karachi, Karachi 75270, Pakistan \\ ${ }^{2}$ Department of Geography, University of Karachi, Karachi 75270, Pakistan \\ *Corresponding authorE-mail: salma_great@yahoo.com
}

Copyright $(\odot) 2014$ Salma Hamza et al. This is an open access article distributed under the Creative Commons Attribution License, which permits unrestricted use, distribution, and reproduction in any medium, provided the original work is properly cited.

\begin{abstract}
A study of ophiolitic rocks, soils, twigs and fruits of Tamarindus indica have been carried out to evaluate elemental relationship. Soil of the study area revealed concentration of trace elements acquired from the bedrock. Its average abundance (mg/kg) in the soil was Mn (30), Fe (28), Pb (5.12), Cr (4.7), Ni (3.12), Cu (2.66), Zn (1.02), Co (0.97) and $\mathrm{Cd}$ (0.49). Fruit pulp presented: Fe (16.0), Cr (5.57), Zn (3.75), Mn (2.99), Cu (2.05), Co (0.92) and Ni (0.24). Twigs of T. indica showed $\mathrm{Fe}>\mathrm{Zn}>\mathrm{Mn}>\mathrm{Cu}>\mathrm{Ni}>\mathrm{Cr}>\mathrm{Pb}>\mathrm{Co}>\mathrm{Cd}$ trend of concentration. Elemental composition of rock-soil-twigfruit of $T$. indica demonstrated similarities in the distribution pattern, reflecting common association between them. Correlation matrix (CM) and principal component analysis (PCA) revealed that elemental distribution of $T$. indica is influenced by the composition of rocks and soils of the study area.
\end{abstract}

Keywords: PCA; Rock-Soil-Twig-Fruit Relation; Element Distribution; Geochemistry; Balochistan

\section{Introduction}

Tamarindus indica (Tamarind) is a well-known plant of the Pakistan. It is a large, evergreen and long-lived tree and widely planted in the study area. It belongs to Leguminosae/Fabaceae family [1]. Fruit of the plant is velvety cinnamon brown in colour and extremely sour in taste. It is mainly used for souring food items and pickles. The fruit has many health beneficial ingredients and is conventionally utilized as a raw material in eastern medicine [2, 3].

Several fruit farms are present in and around Winder town which is situated nearly $80 \mathrm{~km} \mathrm{NW}$ of Karachi city along the RCD Highway, in southern Balochistan (Fig. 1). The area lies at the western margin of the Indian Plate [4]; forming southern part of the Mor range which comprises of sedimentary rocks (Ferozabad Group) of Jurassic age and Bela Ophiolite (BO) of Cretaceous age [5]. Rocks of BO were generated during Neotethyan tectonics showing supra subduction character [6,7]. Majority of igneous rocks are amygdaloidal and vesicular porphyritic basalt in the area. Sedimentary rocks are comprised of clastic and carbonates and contains $\mathrm{Pb}$ - $\mathrm{Zn}$-barite mineralization [8]. These rocks are enriched with appreciable quantities of $\mathrm{Fe}, \mathrm{Mn}, \mathrm{Cr}, \mathrm{Ni}, \mathrm{Co}, \mathrm{Cu}, \mathrm{Zn}, \mathrm{Pb}$ and $\mathrm{Cd}$.

During weathering processes, elements get concentrated in the soils of the study area [9]. Assessment of trace element content of soil is contingent to evaluating the sustainability of the agricultural ecosystem of an area for better crop production and reducing of trace elements intake through food chain [10]. The average water content and organic matter of the soils is $31 \%$ and $2 \%$ respectively. Soil shows $\mathrm{Fe}>\mathrm{Pb}>\mathrm{Cr}>\mathrm{Ni}>\mathrm{Cu}>\mathrm{Zn}>\mathrm{Co}>\mathrm{Cd}$ abundance trend [8]; this shows relevance mainly with $\mathrm{BO}$ of Cretaceous age along with sedimentary rocks of Mor Range of Jurassic age.

The $\mathrm{Cr}, \mathrm{Ni}, \mathrm{Cu}, \mathrm{Co}$ and $\mathrm{Cd}$ in the soil are mainly supplied by ophiolitic rocks while high $\mathrm{Fe}$ and $\mathrm{Zn}$ can be contributed both from ophiolite and sedimentary rocks of the area. Mineralogically, it contains high quartz and calcite along with variable proportions of clay minerals and iron oxides. Presence of clay fraction is responsible for mobilizing $\mathrm{Cr}, \mathrm{Cu}, \mathrm{Zn}$ and $\mathrm{Cd}$ [9]. Bio-available trace elements can be absorbed by the plants through their root systems and translocated to different parts of the plants, including the fruits. The accumulation of trace elements through food chain is probably responsible for the spread of diseases related to toxic elements among the consumers [11]. 
Present study has evaluated the relationship between trace elements assemblage of rocks-soils-twigs and fruits of $T$. indica of the study area with the help of CM and PCA. These are significant statistical methods used to reduce huge data and determine the association of trace elements [12]. It also assessed the amassing of trace elements through geological environment in the locally grown $T$. indica.

\section{Material and methods}

Representative composite samples of 21 igneous rocks, 14 sedimentary rocks, 49 soils, 19 twigs and 15 fruits of $T$. indica were collected from different fruit farms of Winder town. Igneous and clastic sedimentary rock samples were decomposed by flux method [13]. Carbonate rocks were digested using $\mathrm{HCl}(10 \%)$. The resulting solution was transferred to $100 \mathrm{ml}$ volumetric flask [14]. Soil samples $(2 \mathrm{~mm})$ were soaked overnight in double distilled water. Shake on an electric shaker for $2 \mathrm{~h}$. The content was filtered through Whatman No. 42 filter paper in a 100 ml volumetric flask [15]. The twigs were charred slowly at low flame till gray ash was formed in the china dish [16] and then digested with $5 \mathrm{ml}$ concentrated $\mathrm{HNO}_{3}$ [17].

Fresh fruit pulp was treated with $\mathrm{HNO}_{3}$ and heated near to dryness [18]. The residue was treated with $10 \mathrm{ml}$ of concentrated $\mathrm{HCl}$ and after heating for $30 \mathrm{~min}, 20 \mathrm{ml}$ of distilled water was added and solution was further heated for $15 \mathrm{~min}$. The final solution was filtered and made up to $100 \mathrm{ml}$ [19]. Atomic Absorption Spectrometer was used to determine the concentration of the elements in the studied samples.

\subsection{Statistical analysis}

Multivariate analysis was performed using SPSS- 20.0 for Windows. PCA was interpreted in accordance to presence of trace elements combination [20,21]. Varimax rotation was applied for data reduction and results have been shown in a $3 \mathrm{D}$ rotated space of PCA.CM computed through Pearson's technique with degree of significant level was $\mathrm{p}<0.05$.

\section{Results and discussion}

The level of trace element in the fresh fruits of $T$. indica follows $\mathrm{Fe}>\mathrm{Cr}>\mathrm{Zn}>\mathrm{Mn}>\mathrm{Cu}>\mathrm{Co}>\mathrm{Ni}$ trend (Table 1). The Fe shows wide range of concentration, from 33 to $0.49 \mathrm{mg} / \mathrm{kg}$ with an average of $16.17 \mathrm{mg} / \mathrm{kg}$. The average amount of Cr in the pulp of $T$. indica was $5.57 \mathrm{mg} / \mathrm{kg}$ while that of $\mathrm{Zn}$ was $3.75 \mathrm{mg} / \mathrm{kg}$ (Fig. 2A). All other trace elements were found to be $<3 \mathrm{mg} / \mathrm{kg}$. The Ni displays lower levels of concentration among the trace elements (av. $0.24 \mathrm{mg} / \mathrm{kg}$ ). The present work reveals higher $\mathrm{Fe}(16.17 \mathrm{mg} / \mathrm{kg})$ and $\mathrm{Cu}(2.05 \mathrm{mg} / \mathrm{kg})$ concentrations and lower $\mathrm{Zn}(3.75 \mathrm{mg} / \mathrm{kg}) \mathrm{and} \mathrm{Mn}(2.99$ $\mathrm{mg} / \mathrm{kg}$ ), compared to the analytical result of [22] which shows $14.07,0.76,8.52$ and $25.9 \mathrm{mg} / \mathrm{kg}$ respectively, for Fe, $\mathrm{Cu}, \mathrm{Zn}$ and $\mathrm{Mn}$. Twigs of $T$. indica illustrate $\mathrm{Fe}>\mathrm{Zn}>\mathrm{Mn}>\mathrm{Cu}>\mathrm{Ni}>\mathrm{Cr}>\mathrm{Pb}>\mathrm{Co}>\mathrm{Cd}$ trend of concentration (Fig. 2B). The concentration of Fe ranges from 1691 to $4415 \mathrm{mg} / \mathrm{kg}$ with an average of $2578 \mathrm{mg} / \mathrm{kg}$ (Table 2). Zinc is the second most abundant element (av. $410 \mathrm{mg} / \mathrm{kg}$ ) found in the twigs of $T$. indica of Winder area. The average accumulation of $\mathrm{Mn}, \mathrm{Cu}$, $\mathrm{Ni}$ and $\mathrm{Cr}$ is 305, 152, 142 and $92 \mathrm{mg} / \mathrm{kg}$ respectively. Chromium $(92 \mathrm{mg} / \mathrm{kg})$ is much higher than the world average for all plants $(9 \mathrm{mg} / \mathrm{kg})$. Average concentration of $\mathrm{Pb}$ is $51 \mathrm{mg} / \mathrm{kg}$, which is between the $70 \mathrm{mg} / \mathrm{kg}$ of [23] Brooks (1972) and $30 \mathrm{mg} / \mathrm{kg}$ of [24] for common plants. Cadmium is least recorded (av. $4.4 \mathrm{mg} / \mathrm{kg}$ ) in the twigs of $T$. indica. It is a significant toxic element for plants because of its mobility and high solubility in water.

In the Winder area, rocks of BO are exposed and mainly consist of mafic tholeiitic pillow basalts. These rocks are rich in trace elements and display $\mathrm{Fe}>\mathrm{Mn}>\mathrm{Cr}>\mathrm{Ni}>\mathrm{Cu}>\mathrm{Zn}>\mathrm{Co}>\mathrm{Pb}>\mathrm{Cd}$ abundance trend (Table 3). These elements get dispersed in the soil after weathering. The arid climate of the area accumulates more immobile elements (as Fe and Mn) in the soil but the magnitude of concentration is low (Table 3 and Fig. 3). Despite the high concentration of $\mathrm{Cr}$ in the rocks (av. $694 \mathrm{mg} / \mathrm{kg}$ ), it has been noted to be very low in the soil (av. $4.7 \mathrm{mg} / \mathrm{kg}$ ).

Mutual relation among the trace elements composition of rocks, soils, twigs and fruits of $T$. indica has been illustrated in Figure 3. The diagram shows nearly similar distribution pattern, other than a few exception. The diversity is probably due to different in the nature of materials and the mechanisms of enrichment. Similarity in the distribution pattern reflects a pathway in the rock-soil-plant system, responsible for the accumulation of the trace elements in the soils and henceforth, transfers to the twigs and fruits of $T$. indica in the study area.

Ternary diagram (Cr-Ni-Co) illustrates mutual relation between them. Plots of average concentration in rocks, soils, twigs and fruits of $T$. indica were in the array, reflecting genetic association between them (Fig. 4A). Fruits had relatively high $\mathrm{Cr}$, while twigs contained elevated amount of $\mathrm{Ni}$. Iron along with $\mathrm{Mn}$ and $\mathrm{Cr}$ was valuable to infer inherited composition from the rocks and soils of the study area. Twigs, rocks and fruits have been found in close composition, while soils of the Winder area were found to be rich in Mn (Fig. 4B). Liaison of different segments of BO and $T$. indica has also inferred from $\mathrm{Mn}-\mathrm{Co}-\mathrm{Ni}$ triangulation variation diagram. Rocks, soils and twigs show variation in three components, having more Mn and moderate Ni. Soils demonstrate high Mn, medium Co and low Ni (Fig. 4C).

The impact of ophiolitic rocks of the study area can also be visualized from the results of CM. Pairs of trace elements in rocks, soils, twigs and fruits show good relation between them, reflecting close association and even generation from the same source (Table 4). The trace elements of ophiolitic rocks show good correlation between $\mathrm{Fe}-\mathrm{Cd}, \mathrm{Cu}-\mathrm{Cd}, \mathrm{Zn}-\mathrm{Cd}$, 
Mn-Zn, Mn-Cd (Table 4). Similarly, trace elements assemblage within the soil of the study area also demonstrates mutual relationship. The Fe shows good correlation with $\mathrm{Mn}, \mathrm{Cd}$ and $\mathrm{Ni}$; while $\mathrm{Cd}$ has good relation with $\mathrm{Mn}$ and $\mathrm{Ni}$. Such geochemical relations are not unexpected in mafic rocks. The positive correlation among the important trace elements of the soils of the study area suggests similarity in composition. Negative relation of $\mathrm{Pb}$ with $\mathrm{Mn}, \mathrm{Ni}$ and $\mathrm{Fe}$ (Table 4), indicate probable source of $\mathrm{Pb}$ from Sedex-type sedimentary rocks, which are widely exposed in the study area [25].

The rock-fruit relation is linked through twigs and is influenced by the composition of the soil. The mutual association between the elements also exists in the elemental composition of twigs. The young twigs of T. indica display strong to moderate correlation (Table 4). The fleshy part of $T$. indica shows strong CM ( $\mathrm{r}=0.842)$ between $\mathrm{Cr}$ and $\mathrm{Co}$. In the current study $\mathrm{Cr}-\mathrm{Ni}-\mathrm{Co}-\mathrm{Mn}-\mathrm{Cu}$ positive relation indicates that the fruits of $T$. indica accumulate these elements with nearly equal ease from the soils.

Table 1: Concentration of Selected Trace Elements $(\mathrm{mg} / \mathrm{kg})$ In Fruits of T. Indica

\begin{tabular}{|c|c|c|c|c|c|c|c|}
\hline Sample & $\mathrm{Cu}$ & $\mathrm{Zn}$ & $\mathrm{Ni}$ & $\mathrm{Fe}$ & $\mathrm{Co}$ & $\mathrm{Mn}$ & $\mathrm{Cr}$ \\
\hline \multicolumn{8}{|l|}{ Sites } \\
\hline SB & 6.6 & 6 & 0.3 & 11 & 0 & 1.1 & 2.7 \\
\hline $\mathrm{HC}$ & 5.6 & 5.5 & 0.3 & 25 & 1.6 & 2.5 & 8.5 \\
\hline $\mathrm{AH}$ & 0.8 & 5.7 & 0.3 & 1.1 & 1.1 & 5.9 & 5.1 \\
\hline GD & 0.8 & 1.7 & 0.2 & 33 & 1.1 & 2.2 & 5.2 \\
\hline QS & 1.1 & 3.2 & 0.2 & 16 & 1.5 & 3.6 & 11 \\
\hline RB & 1.1 & 5.6 & 0.3 & 30 & 0.9 & 3.8 & 4.5 \\
\hline GF & 4.5 & 2.5 & 0.4 & 10 & 0.3 & 1.2 & 1.5 \\
\hline NS & 4.5 & 3.2 & 0.2 & 14 & 0.3 & 2.4 & 1.8 \\
\hline WT & 0.7 & 6.4 & 0.3 & 17 & 0.8 & 2.7 & 4.8 \\
\hline $\mathrm{HG}$ & 0.7 & 2.5 & 0.2 & 6.1 & 0.6 & 3.1 & 4.9 \\
\hline HM & 0.8 & 3 & 0.3 & 0.5 & 1.4 & 5 & 5.4 \\
\hline UG & 0.8 & 1.9 & 0.3 & 24 & 0.6 & 2.1 & 4.9 \\
\hline KR & 0.8 & 3.1 & 0.1 & 5 & 0.7 & 2.8 & 5.1 \\
\hline $\mathrm{CF}$ & 1.1 & 3.3 & 0.2 & 28 & 1.6 & 2.8 & 7.2 \\
\hline $\mathrm{MN}$ & 1 & 2.8 & 0.2 & 22 & 1.4 & 3.8 & 11 \\
\hline Mean & 2.1 & 3.8 & 0.2 & 16 & 0.9 & 3 & 5.6 \\
\hline
\end{tabular}

Table 2: Concentration of Selected Elements (mg/kg) In Twigs of T. Indica

\begin{tabular}{|c|c|c|c|c|c|c|c|c|c|}
\hline Sample & $\mathrm{Cu}$ & $\mathrm{Pb}$ & $\mathrm{Zn}$ & $\mathrm{Ni}$ & $\mathrm{Fe}$ & $\mathrm{Co}$ & $\mathrm{Mn}$ & $\mathrm{Cr}$ & $\mathrm{Cd}$ \\
\hline \multicolumn{10}{|l|}{ Sites } \\
\hline SP & 145 & 70 & 430 & 267 & 2004 & 2.1 & 479 & 93 & 7.5 \\
\hline SB & 321 & 99 & 646 & 304 & 1691 & 2.8 & 320 & 106 & 9.5 \\
\hline $\mathrm{GH}$ & 179 & 46 & 348 & 242 & 1878 & 1.5 & 272 & 72 & 4.5 \\
\hline HS & 107 & 39 & 622 & 287 & 2286 & 1.4 & 250 & 88 & 5.2 \\
\hline $\mathrm{AK}$ & 206 & 74 & 636 & 2.3 & 2303 & 2 & 560 & 111 & 5.9 \\
\hline $\mathrm{HC}$ & 126 & 7.5 & 349 & 36 & 2601 & 1.6 & 301 & 57 & 0.4 \\
\hline $\mathrm{AH}$ & 266 & 103 & 1043 & 281 & 2730 & 2.9 & 569 & 144 & 9.3 \\
\hline $\mathrm{HF}$ & 124 & 97 & 551 & 322 & 2386 & 2.7 & 223 & 126 & 13 \\
\hline GX & 130 & 64 & 232 & 161 & 2580 & 1.4 & 275 & 96 & 4.8 \\
\hline QS & 112 & 15 & 2 & 148 & 2634 & 1.5 & 219 & 107 & 4.8 \\
\hline $\mathrm{AR}$ & 113 & 46 & 288 & 85 & 3589 & 21 & 322 & 93 & 1.5 \\
\hline $\mathrm{RB}$ & 218 & 46 & 401 & 88 & 2657 & 19 & 220 & 86 & 1.1 \\
\hline $\mathrm{CU}$ & 139 & 51 & 268 & 44 & 3147 & 23 & 239 & 91 & 1.7 \\
\hline GP & 90 & 49 & 156 & 68 & 2524 & 16 & 293 & 82 & 4.6 \\
\hline GF & 137 & 57 & 361 & 77 & 4415 & 18 & 309 & 105 & 2 \\
\hline GE & 88 & 59 & 444 & 70 & 2170 & 17 & 246 & 80 & 2.3 \\
\hline NS & 128 & 16 & 310 & 154 & 2635 & 11 & 305 & 110 & 3.8 \\
\hline TA & 168 & 23 & 296 & 30 & 2464 & 1.5 & 200 & 47 & 0.7 \\
\hline $\mathrm{MN}$ & 93 & 12 & 403 & 33 & 2297 & 1.7 & 191 & 59 & 0.5 \\
\hline Mean & 152 & 51 & 410 & 142 & 2578 & 8 & 305 & 92 & 4.4 \\
\hline
\end{tabular}

Table 3: Concentration of Selected Elements $(\mathrm{mg} / \mathrm{kg})$ In Rocks and Soils of Winder Area

\begin{tabular}{|c|c|c|c|c|c|c|c|c|c|}
\hline \multicolumn{5}{|c|}{ Rocks $(\mathrm{n}=35)$} & \multicolumn{5}{|c|}{ Soils $(n=49)$} \\
\hline Elements & Min & Maz & Mean & SD & Elements & Min & $\operatorname{Max}$ & Mean & SD \\
\hline $\mathrm{Cu}$ & 2.6 & 422 & 245 & 132 & $\mathrm{Cu}$ & 0.03 & 8.8 & 2.66 & 2.73 \\
\hline $\mathrm{Zn}$ & 2.2 & 141 & 79 & 35 & $\mathrm{Zn}$ & 0.03 & 16.7 & 1.02 & 2.67 \\
\hline $\mathrm{Ni}$ & 5.4 & 1410 & 635 & 372 & $\mathrm{Ni}$ & 0.52 & 13.3 & 3.12 & 2.9 \\
\hline $\mathrm{Fe}$ & 156 & 11984 & 5044 & 4,062 & $\mathrm{Fe}$ & 0.8 & 197 & 28 & 46 \\
\hline $\mathrm{Co}$ & 12 & 103 & 62.8 & 24 & Co & 0.05 & 2 & 0.97 & 0.38 \\
\hline Mn & 42 & 2252 & 907 & 511 & Mn & 1.23 & 140 & 30 & 39 \\
\hline $\mathrm{Cr}$ & 12 & 3984 & 694 & 854 & $\mathrm{Cr}$ & 0.07 & 9.8 & 4.7 & 2.61 \\
\hline $\mathrm{Pb}$ & 1.2 & 97 & 58 & 36 & $\mathrm{~Pb}$ & 0.08 & 10.55 & 5.12 & 4.14 \\
\hline $\mathrm{Cd}$ & 0.9 & 6 & 3.8 & 1.66 & $\mathrm{Cd}$ & 0.13 & 1.8 & 0.49 & 0.46 \\
\hline
\end{tabular}


Table 4: Correlation Coefficient between Elements Concentration in Rocks, Soils and Plants (Twigs and Fruits) of T. Indica

\begin{tabular}{|c|c|c|c|c|c|c|c|}
\hline \multicolumn{2}{|c|}{ Rock } & \multicolumn{2}{|c|}{ Soil } & \multicolumn{2}{|c|}{ Twigs (T. indica) } & \multicolumn{2}{|c|}{ Fruit (T. indica) } \\
\hline $\mathrm{Fe}-\mathrm{Cd}$ & 0.899 & $\mathrm{Fe}-\mathrm{Mn}$ & 0.983 & $\mathrm{Ni}-\mathrm{Cd}$ & 0.811 & $\mathrm{Cr}-\mathrm{Co}$ & 0.842 \\
\hline $\mathrm{Cu}-\mathrm{Cd}$ & 0.871 & $\mathrm{Fe}-\mathrm{Cd}$ & 0.911 & $\mathrm{~Pb}-\mathrm{Cd}$ & 0.775 & $\mathrm{Mn}-\mathrm{Co}$ & 0.554 \\
\hline $\mathrm{Zn}-\mathrm{Cd}$ & 0.737 & $\mathrm{Mn}-\mathrm{Cd}$ & 0.903 & $\mathrm{Cr}-\mathrm{Cd}$ & 0.724 & $\mathrm{Mn}-\mathrm{Cr}$ & 0.381 \\
\hline $\mathrm{Mn}-\mathrm{Zn}$ & 0.667 & $\mathrm{Mn}-\mathrm{Ni}$ & 0.866 & $\mathrm{Cr}-\mathrm{Pb}$ & 0.685 & $\mathrm{Ni}-\mathrm{Cu}$ & 0.314 \\
\hline $\mathrm{Mn}-\mathrm{Cd}$ & 0.626 & $\mathrm{Fe}-\mathrm{Ni}$ & 0.843 & $\mathrm{Zn}-\mathrm{Pb}$ & 0.66 & $\mathrm{Ni}-\mathrm{Zn}$ & 0.294 \\
\hline $\mathrm{Cu}-\mathrm{Zn}$ & 0.571 & $\mathrm{Cd}-\mathrm{Ni}$ & 0.789 & $\mathrm{Zn}-\mathrm{Cu}$ & 0.606 & $\mathrm{Mn}-\mathrm{Cu}$ & -0.569 \\
\hline $\mathrm{Cu}-\mathrm{Fe}$ & 0.541 & $\mathrm{~Pb}-\mathrm{Mn}$ & -0.632 & $\mathrm{Fe}-\mathrm{Co}$ & 0.606 & $\mathrm{Co}-\mathrm{Cu}$ & -0.373 \\
\hline $\mathrm{Cr}-\mathrm{Co}$ & 0.539 & $\mathrm{~Pb}-\mathrm{Ni}$ & -0.568 & $\mathrm{Mn}-\mathrm{Zn}$ & 0.605 & $\mathrm{Cr}-\mathrm{Cu}$ & -0.35 \\
\hline $\mathrm{Co}-\mathrm{Pb}$ & -0.756 & $\mathrm{~Pb}-\mathrm{Fe}$ & -0.567 & $\mathrm{~Pb}-\mathrm{Cu}$ & 0.575 & Fe-Mn & -0.328 \\
\hline
\end{tabular}

The average Cr content was considered to be high $(5.57 \mathrm{mg} / \mathrm{kg})$ as compared to $2.9 \mathrm{mg} / \mathrm{kg}$ of [26] for all native floras. Possibly, the high amount of $\mathrm{Cr}$ has due to the presence of extraordinarily high amount ( 10\%) of tartaric acid in the fruit [27]. Tartaric acid reduced $\mathrm{Cr}^{6+}$ (atomic size $0.75 \AA$ ) to $\mathrm{Cr}^{3+}$ (size $0.58 \AA$ ), which is compatible to many divalent ions, thus $\mathrm{Cr}$ is enriched in the fruit pulp.

Based on rotated component matrix, trace elements have been observed significant group combination in the rock samples. First combination consists on $\mathrm{Fe}(0.90), \mathrm{Mn}(0.88), \mathrm{Ni}(0.87)$ and $\mathrm{Cr}(0.81)$, while, $\mathrm{Co}(0.92), \mathrm{Cd}(0.89)$ and $\mathrm{Cu}(0.87)$ has shown as second group of combination. $\mathrm{Zn}(0.70$ and 0.61$)$ associated among both combinations and its role can be defined as bridge (Fig. 5). Concentration of $\mathrm{Pb}$ in rock sample has depicted independent role, probably it is related to Sedex type of mineralization as referred before. Soil sample sites of $T$. indica were identified strongest group combination on the basis of selected trace metals concentration (Fig. 5). Closet group chain has been developed by Mn (0.98), $\mathrm{Fe}(0.97)$ and $\mathrm{Cd}(0.90)$ and associated character can be provided from $\mathrm{Ni}(0.88)$ and $\mathrm{Zn}(0.76)$. This combination also produced repels force against $\mathrm{Pb}(-0.67)$. The content of $\mathrm{Cr}, \mathrm{Cu}$ and $\mathrm{Pb}$ can be defined as weak group due to their correlations $(0.87),(0.74)$ and $(0.51)$. The concentration of Co has identified as independent role in the soils which is most distinguished comparatively rock combinations (Fig. 5).

Three distinct groups of combinations have been observed in twigs of $T$. indica (Fig. 5). Cadmium (0.88), Ni (0.82) and $\mathrm{Cr}(0.80)$ concentration intake in twigs depict strong interaction among them in terms of injection while $\mathrm{Mn}(0.83), \mathrm{Zn}$ $(0.78)$ and $\mathrm{Cu}(0.77)$ were arranges as second combination in the twigs of $T$. indica although $\mathrm{Pb}$ concentration has distinct as associated member and bridge between both combinations with its correlation (0.69) and (0.57). Third group combination consists on $\mathrm{Fe}(0.89)$ and $\mathrm{Co}(0.85)$ which can be identified as closet with each other and $\mathrm{Ni}(-0.41)$ try to producing resistance against them.

Due to significance of factor analysis, various scholars have also utilized PCA in the assessment of fruit composition $[28,29]$. In the fruits of $T$. indica, rotated component matrix, demonstrate three separate populations (Fig.5). In component 1, $\mathrm{Co}(0.95), \mathrm{Cr}(0.87)$ and $\mathrm{Mn}(0.64)$ are strongly associated, but $\mathrm{Cu}(-0.51)$ has shown inverse trend while, second component has shown Zinc (0.82), $\mathrm{Ni}(0.75)$ and $\mathrm{Cu}(0.60)$ part of its members. Third combination of trace minerals consist on $\mathrm{Fe}(0.86)$ and $\mathrm{Mn}(-0.71)$ in which their opposite characters can be identified (Fig. 5).

\section{Conclusions}

Average elemental composition of T. indica fruits showed $\mathrm{Fe}$ (16.17), $\mathrm{Cr}$ (5.57) while $\mathrm{Zn}$ is $3.75 \mathrm{mg} / \mathrm{kg}$. Rest of the elements $(\mathrm{Mn}, \mathrm{Cu}, \mathrm{Co}, \mathrm{Ni})$ is $<3 \mathrm{mg} / \mathrm{kg}$. Twigs of $T$. indica illustrate $\mathrm{Fe}>\mathrm{Zn}>\mathrm{Mn}>\mathrm{Cu}>\mathrm{Ni}>\mathrm{Cr}>\mathrm{Pb}>\mathrm{Co}>\mathrm{Cd}$ trend of distribution and their average concentration are $2578,410,152,142,92,51,8$ and $4.4 \mathrm{mg} / \mathrm{kg}$ respectively. The amount of $\mathrm{Cr}$ (av. 92) in the twig is high then the average value of $\mathrm{Cr}(9 \mathrm{mg} / \mathrm{kg})$ in the common plants of the world. In general, magnitude of concentration of elements in twigs is high in contrast to fruit values. The twig/fruit ratio of $T$. indica was noted minimum in case of $\mathrm{Co}(8.6)$ and maximum found in $\mathrm{Ni}$ (591.6), indicating restriction in the transformation of $\mathrm{Ni}$ from twig to fruit. $T$. indica, a local fruit plant is widely cultivated over the soil of the study area, which are derived mainly from the weathering of igneous (BO) and sedimentary rocks of Jurassic age. Average composition of the soil showed high $\mathrm{Mn}$ (30) and $\mathrm{Fe}(28 \mathrm{mg} / \mathrm{kg}$ ); moderate $\mathrm{Pb}$ (5.12), $\mathrm{Cr}$ (4.7), $\mathrm{Ni}$ (3.12), $\mathrm{Cu}$ (2.66) and low $\mathrm{Zn}$ (1.02), Co $(0.97) \mathrm{Cd}(0.49 \mathrm{mg} / \mathrm{kg})$. Elemental composition of rock-soil-plant on log scale and ternary plots displays near identical distribution pattern, reflecting mutual relation among them. Statistical analysis in terms of CM and PCA revealed that elemental distribution of $T$. indica is influenced by the composition of rocks, minerals and soils of the study area. 

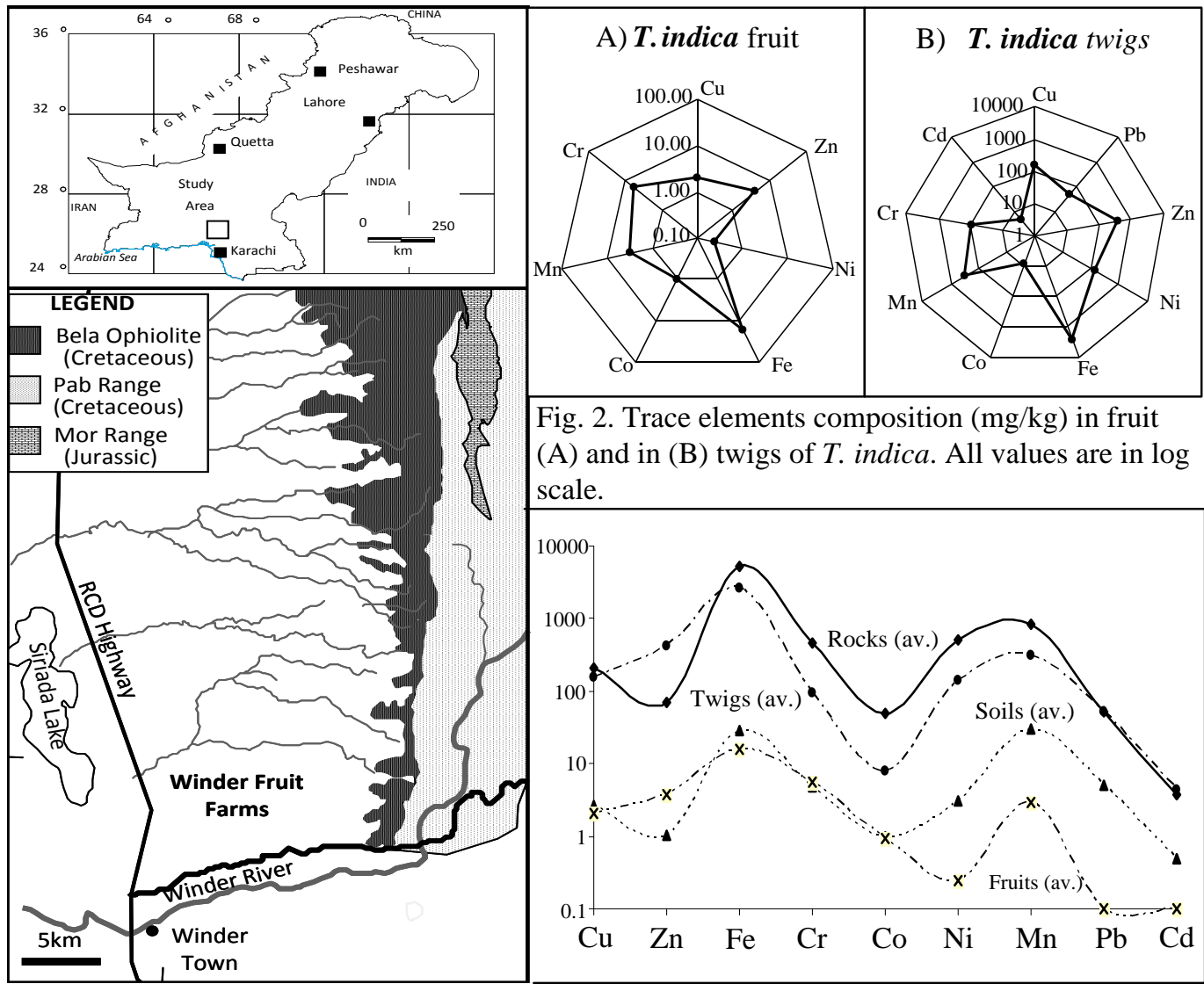

Fig. 1. Geological map of Winder and adjoining areas

Fig. 2. Trace elements composition $(\mathrm{mg} / \mathrm{kg})$ in fruit (A) and in (B) twigs of $T$. indica. All values are in $\log$ scale.

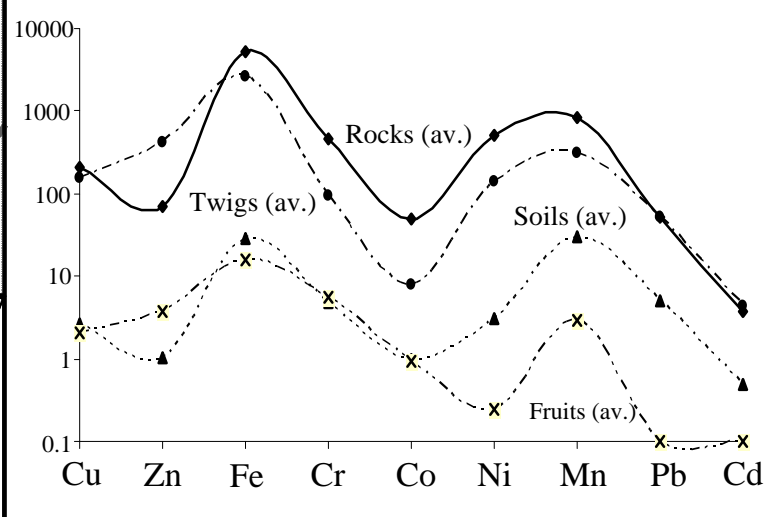

Fig. 3. Distribution of the studied elements $(\mathrm{mg} / \mathrm{kg})$ in

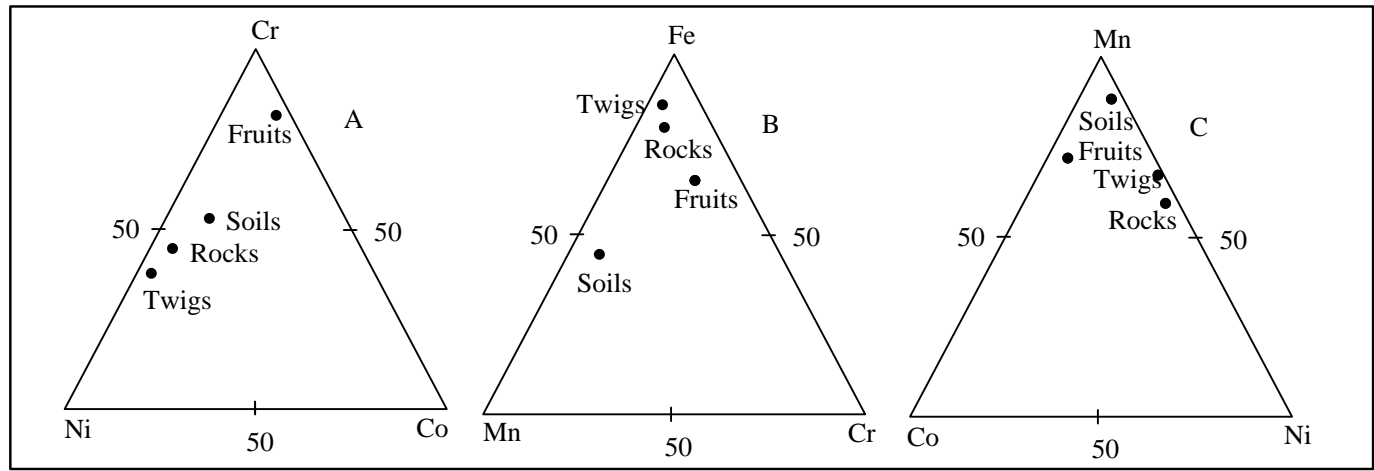

Fig.4. Relation between rocks, soils and plants (twigs and fruits) of $T$. indica

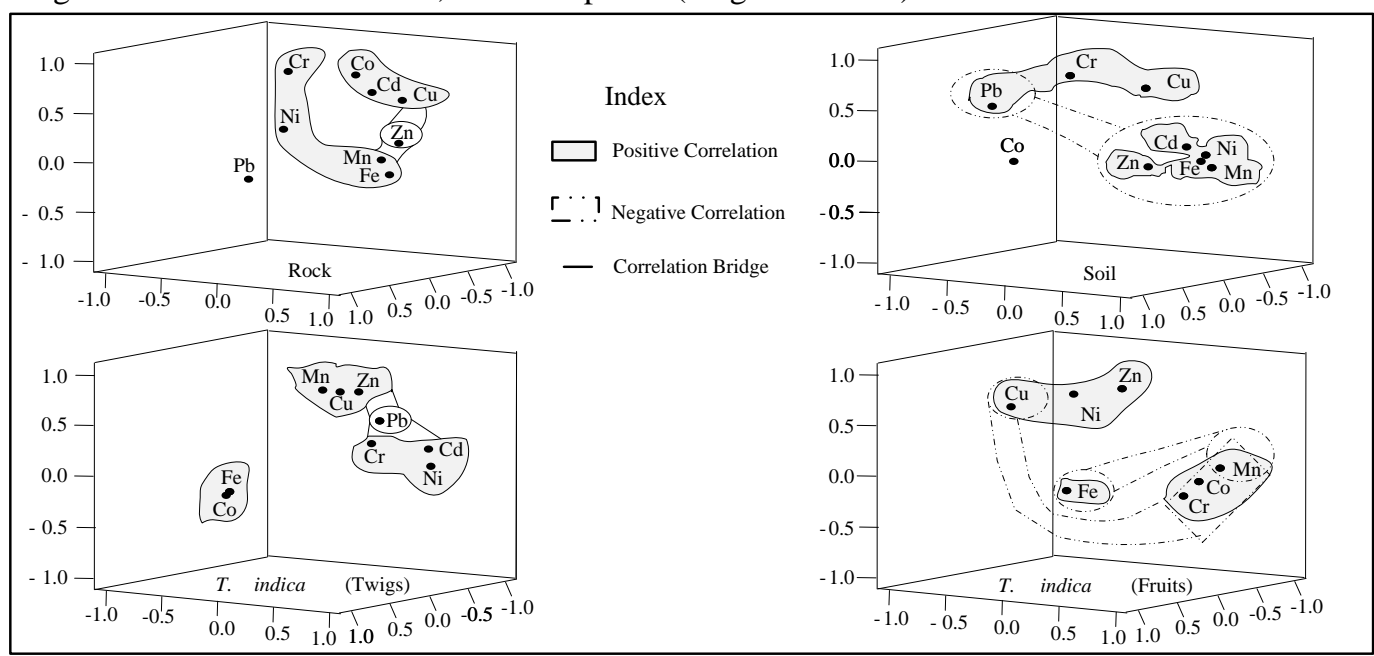

Fig. 5. Results of the PCA for rocks, soils, twigs and plants (twigs and fruits) of $T$. indica 


\section{References}

[1] Lewis G, Schrire B, Mackinder B, Lock M (2005) Legumes of the World. Royal Botnaic Gardens, Kew.

[2] Ara N. Monirul Islam MD (2009) phytochemical screening and in vitro antibacterial activity of $T$. indica seeds ethanolic extract. Pak J Pharmacol, 26: 19-23.

[3] Iftekhar ASM, Rayhan I, Quadir MA, Akhteruzzaman S, Hasnat A (2006) Effect of T. indica fruits on blood pressure and lipid-profile in human model: an in vivo approach. Pak J Pharm Sci, 19:125-129.

[4] Dilek Y, Thy P (2009) Island arc tholeiite to boninitic melt evolution of the Cretaceous Kizildag (Turkey) ophiolite: Model for multi-stage early arc-forearc magmatism in Tethyan subduction factories. Lithos, 113: 68-87.

[5] Naseem S. Hamza S. Bashir E (2010) Groundwater geochemistry of Winder Agricultural Farms, Balochistan, Pakistan and assessment for irrigation water quality. European Water, 31: 21-32.

[6] Yaliniz MK, Floyd PA, Goncuoglu MC (1996) Supra-subduction zone ophiolites of Central Anatolia: geochemical evidence from the Sarikaraman Ophiolite, Aksaray, Turkey. Mineralogical Magazine, 60: 697-710.

[7] Pearce JA, Lippard SJ, Roberts S (1994) Characteristics and tectonic significance of supra-subduction zone ophiolites. In: Kokelaar BP, Howels MF (eds) Marginal basin geology: volcanic and associated sedimentary and tectonic processes in modern and ancient marginal basins. Geol Soc Sp. Publication 16, London, 77-94.

[8] Hamza S, (2011) Influence of Ophiolitic and Sedimentary Rocks on the Cultivated and Wild Vegetations of Winder Agriculture Farms, Balochistan Pakistan. Ph.D. Dissertation, Federal Urdu University of Arts, Science and Technology, University Road, Karachi.

[9] Naseem S, Hamza S, Bashir E (2012a) Assessment of geochemistry of soils for agriculture at Winder, Balochistan, Pakistan. In: Lee TS (ed) Water quality, soil and managing irrigation of crops, InTech - Open Access Publisher, Croatia, 73-94.

[10] Rivelli AR, Puschenreiter M, DeMaria S (2014) Assessment of Cd uptake and nutrient contentin sunflower plants grown under Cd stress. Plant Soil Environ, 60: 80-86.

[11] Lindh U (2005) Biological functions of the elements. In: Selinus O, Alloway B, Centeno JA, Finkelman RB, Fuge R, Lindh U, Smedley P (eds), Essentials of medical geology. Amsterdam, Elsevier, 115-160.

[12] Patras A, Brunton NP, Downey G, Rawson A, Warriner K, Gernigon G (2011) Application of principal component and hierarchical cluster analysis to classify fruits and vegetables commonly consumed in Ireland based on in vitro antioxidant activity. Journal of Food Composition and Analysis, 24: 250-256.

[13] Gill R (2000) Modern analytical geochemistry (Longman Geochemistry Series). Addison Wesley Longman, USA.

[14] Jeffery PG, Hutchison D (1983) Chemical method of rock analysis. Pergamon Press, UK.

[15] Gupta PK (2004) Methods in environmental analysis water, soil and air. Agrobio, India.

[16] Martin HW, Young TR, Kaplan DI, Simon L, Adriano DC (1996) Evaluation of three herbaceous index plant species for bioavailability of soil cadmium, chromium, nickel and vanadium. Plant and Soil, 182: 199-207.

[17] Jones JB Jr, Case VW (1990) Sampling, handling, and analyzing plant tissue samples. In: Westarman RL (ed) Soil testing and plant analysis 3rd edn. Soil Science Society of America Inc, Madison, WI, 389-427.

[18] Ranganna S (2008) Analysis and quality control for fruit and vegetable products. Tata McGraw-Hill Pub Co, New Delhi.

[19] Hashmi DR, Ismail S, Shaikh GH (2007) Assessment of the level of trace metals in commonly edible vegetables locally available in the markets of Karachi City. Pak J Bot, 39: 747-751.

[20] Abid M, Ahmed N, Qayyum MF, Shaaban M, Rashid A (2013) Residual and cumulative effect of fertilizer zinc applied in wheat-cotton production system in an irrigated aridisol. Plant Soil Environment, 59: 505-510.

[21] Huda SN, Burke F, Azam M, Gadiwala S (2013): Social and economic inequality in Sindh - A factorial analysis approach. Int. J. Sociol. Anthropol, 5: 205-218.

[22] Khanzada SK, Shaikh W, Sofia S, Kazi TG, Usmanghani K, Kabir A, Sheerazi TH (2008) Chemical constituents of T. indica medicinal plant in Sindh. Pak J Bot, 40: 2553-2559.

[23] Brooks RR (1972) Geobotany and biogeochemistry in mineral exploration. Harper \& Row Publisher, New York.

[24] Rose AW, Hawkes HE, Webb JS (1979) Geochemistry in mineral exploration. 2nd ed. Academic Press, London.

[25] Naseem S, Hamza S, Bashir E, Ahsan SN, Sheikh SA (2012b) Petrography, geochemistry and tectonic setting of mafic rocks of southern Bela Ophiolite, Balochistan. N York Sci J, 5:1-8.

[26] Glew RS, VanderJagt DJ, Chuang LT, Huang YS, Millson M, Glew RH (2005) Nutrient content of four edible wild plants from West Africa. Plant Foods for Human Nutrition, 60: 187-193.

[27] El-Siddig K, Ebert G, Lüdders P (1999) Tamarind (T. indica L.): A review on a multipurpose tree with promising future in the Sudan. J Appl Bot- Angewandte Botanik, 73: 202-205.

[28] Maisuthisakula P, Pasukb S, Ritthiruangdej P (2008) Relationship between antioxidant properties and chemical composition of some Thai plants. J Food Compos Analysis, 21: 229-240.

[29] Pestana M, Beja P, Correia PJ, DeVarennes A, Faria EA (2005) Relationships between nutrient composition of flowers and fruit quality in orange trees grown in calcareous soil. Tree Physiol, 25: 761-767. 